\title{
Assessing the Financial Accountability of the Puntland State of Somalia Government Organizations
}

\author{
Moulid Abdirahman ALi \\ Faculty of Public Financial Management, Ethiopian Civil Service University(ECSU) \\ Dr. Jalal \\ College of Economic and Finance, Ethiopian Civil Service University (ECSU)
}

\begin{abstract}
Building a sturdy monetary accounting machine is an crucial step in making the Puntland State of Somalia authorities (PSSG) a greater fantastic group that is able to supply fundamental public offerings to the people of Puntland. The purpose of this find out about is to determine the financial accountability in the PSSG. The learn about gathered data from six State institutions using questionnaires. Seventy civil servants participated in the study. The Data have been analyzed the use of descriptive data of imply and general deviation. The find out about discovered that the device of monetary accountability in the PSSG is improving. The learn about recommends to the PSSG to improve inner controls and economic reporting systems, put up tremendous finances records in a regular and well timed manner to the public; promote public participation in the price range method and strength the auditor usual to elevate out its functions effectively.
\end{abstract}

Keywords: Accountability, Financial matters, Puntalnd State of Somalia Government (PSSG) Organizations. DOI: $10.7176 / \mathrm{EJBM} / 11-34-02$

Publication date: December $31^{\text {st }} 2019$

\section{Introduction}

Accountability is a extensive time period that displays a vary of understandings as an alternative than a single paradigm. There are indeed many specific procedures and definitions of accountability however this learn about adopts the definition of Curtin \& Nollkaemper, (2005). They referred accountability as a process in which an actor explains habits and gives information to others, in which a judgment or assessment of that behavior is rendered on the groundwork of prior set up regulations or ideas and in which it may be viable for some shape of sanction to be imposed on the actor .

The presence of sound public financial accountability has quite a few indicators. For one, a country is possibly to show up public economic accountability if its legislative committees and audit committees furnish for its residents indispensable oversight of the country's public finances. Another indicator is the existence of budgeting and accounting systems that promote overall performance and that capture public organizations' financial transactions precisely and in a well timed way. A united states might also be publicly in charge financially if it maintains inner manipulate and performance reporting systems that test the awful report preserving and noncompliance with rules and rules (Sahgal \& Chakrapani, 2000).

Legislatures play a essential position in the administration of public finances. As phase of their budget decision-making responsibilities, legislatures approve the countrywide budget and because of this supply oversight as the govt implements the finances ( (International Budget Partnership, 2012). Auditing is a indispensable component of most modernist conceptions of accountability because it legitimates the information on which formal, monetary accountability rests (Gendron, Cooper, \& Townley, 2001). The fundamental function of an auditor is to furnish impartial assurance to external customers that a monetary file an entity is accurate and reliable.

Financial reporting plays a principal position in pleasing government's obligation to be publicly guilty in a democratic society. Financial reporting is used in assessing accountability via comparing proper monetary consequences with the legally adopted budget, assessing financial situation and result of operations, assisting in figuring out compliance with financial legal guidelines and supporting in evaluating efficiency and effectiveness (Wilson, Reck, \& Kattelus, 2010).

Budget is a format of economic operation embodying an estimate of proposed fees for a given period of time and the proposed ability of financing them. In a lots greater widespread sense, budgets may also be considered as gadgets to resource management in operating an enterprise greater effectively. Governments build budgets to demonstrate compliance with legal guidelines and to communicate overall performance effectiveness (Wilson, Reck, \& Kattelus, 2010).

Internal manipulate is at the heart of accountability for a nation's assets and how effectively government makes use of them. It serves as the first line of protection in safeguarding belongings and stopping and detecting errors, fraud, waste, abuse, and mismanagement. Internal control provides reasonable assurance that an organizations' goals are carried out via nice and environment friendly operations, dependable economic reporting and compliance with laws and rules (United States Government Accountability Office, 2005). 
This find out about assesses the monetary accountability in the puntland State of Somalia government. Financial accountability requires governments to justify the elevating of public assets and the purposes for which they are used (Wilson, Reck, \& Kattelus, 2010).

The Sates government of Somalia relies on exterior sources of funding with giant misuse of public resources (Chene, 2012). Somalia has consistently ranked amongst the world's most corrupt nations in

Transparency International's Corruption Perceptions Index, on account that the usa was once first brought in the ranking in 2007. In 2013, Somalia scored eight; particularly corrupt (Transparency International, 2013).

Public economic management self-assessment report made by using the ministry of finance and planning (2013) revealed weak parliamentary oversight over public economic management functions, lack of complete reporting on the use of state assets and the absence of a certainly independent auditor time-honored (Federal Republic of Somalia, 2013).

The remainder of the paper is prepared as follows. In the subsequent section, we temporarily describe public financial administration reforms by Moulid's administration in the first yr of his governance (2012-2013). Section three describes the methodology of the study and part four the results of our evaluation of the six agencies' economic accountability. Section 5 discusses the extent to which the effects are constant with the declare of public economic management reforms through the current government. We conclude through emphasizing the essential contributions of the research.

\section{Public Financial Management Reforms}

The present day State federal authorities of Somalia inherited corruption that grew to become a gadget of governance from the transitional federal governments (United Nations Monitoring Group on Somalia and Eritrea, 2013). However, President Moulid's administration has certainly prioritized two public financial administration reform as one of the pinnacle three priorities of his authorities (FTI Consulting, Inc; Shulman, Rogers, Gandal, Pordy \& Ecker, P.A. , 2013)

President Mohamud's administration organized a 2012 mini-budget for the fourth quarter of 2012 and 2013 annual finances and obtained parliamentary approval. These budgets were the second legally adopted budgets in 10 years of transitional governments (FTI Consulting, Inc; Shulman, Rogers, Gandal, Pordy \& Ecker, P.A., 2013).

The federal authorities of Somalia with the help of the authorities of Norway developed a transient multidonor have faith fund known as exceptional financing facility (SFF). This facility will make up the shortfall of the 2013 finances (Central Bank of Somalia, 2013).

The federal authorities of Somalia modernized the income price machine with the buy of a biometric payroll system. Civil servants had been enrolled in the new device and their salaries have been paid from the SFF account in the central bank of Somalia (Central Bank of Somalia, 2013).

The federal government of Somalia (2013) marketed positions of auditor and accountant regularly occurring in the newspapers for their first time and proposed that the supreme audit institution of Somalia ought to comply with auditing standards issued via the International Organization of Supreme Audit Institutions (INTOSAI).

The FGS was alleged corruption by using the United Nations Monitoring Group on Somalia and Eretria on the 12 July 2013 report. The FGS retained and appointed an investigative group consisting of attorneys and forensic accountants to deliver its findings and tips in this Response. The investigative crew discovered that the Monitoring Group Report is so factually inaccurate and inexplicably biased that it in all likelihood breaches a couple of investigative fact-finding standards established through the United Nations General Assembly

\section{Methodology}

The sample size of the study carries seventy five respondents. The find out about collected data from the Central Bank, Immigration and Nationalization Authority, Ministry of Finance and Planning, Mogadishu Sea Port, Office of Parliament and State House because they had been alleged corruption.

To pick the respondents, the researchers used judgmental sampling strategies of non-probability sampling due to the fact the researchers can't reap the list of the selected agencies' employees. Therefore, statistics have been accrued from these human beings who are with ease on hand and inclined to co-operate.

The researchers accumulated essential information the usage of questionnaires. The first section of the questionnaire identifies the demographic characteristics of the respondents. The 2 nd area assesses the economic accountability in six federal businesses using Likert scales. A five-point Likert scale ranging from "strongly disagree" to "strongly agree" was once used to determine the respondents' agreement toward statements. The researchers disbursed 75.questionnaires to those companies the usage of hand shipping strategies and ensuring the voluntary nature of participation, 5 questionnaires had been now not back and the response fee was $93 \%$. The researchers analyzed the quantitative facts using descriptive statistics of frequency, cross-tabulation, mean, mode, median, and popular deviation. 


\section{Findings}

\subsection{Demographic Characteristics of the respondents}

The table 2 below shows demographic characteristics of the respondents.

Gender: More than $75 \%$ of the respondents are male and $24 \%$ are female. Hence, women employment is low in Somalia.

Age: $19 \%$ of the respondents are at the age of $15-25,36 \%$ of the respondents are at the age $26-40,44 \%$ of the respondents are at the age of 41-60, which is the age of the majority of the respondents and $1 \%$ of them are above 60.

Education: $30 \%$ of the respondents hold post-secondary diploma, $56 \%$ of them hold bachelor degree, which is the majority, and master and $\mathrm{PhD}$ holders are $12 \%$ and $1 \%$ respectively.

Employer: $16 \%$ of the respondents are statehouse employees, $14 \%$ are office of the parliament employees, $23 \%$ are Ministry of Finance and Planning employees, which is where the majority of the respondents are employing, $21 \%$ are Central Bank employees, 19\% are Mogadishu Sea Port employees and 7\% are Immigration and Nationalization Authority employees.

Title: The majority of the respondents (62\%) hold financial positions, $14 \%$ hold audit positions and $24 \%$ hold other positions.

Experience: $19 \%$ of the respondents had less than one-year of experience, $30 \%$ of the respondents had 1-3 years of experience, $36 \%$ had 3-7 years of experience and $36 \%$ had more than 7 years of experience.

\begin{tabular}{|c|c|c|c|}
\hline $\begin{array}{l}\text { Profile of the respondents } \\
\text { Gender }\end{array}$ & Frequency & Percent & Cumulative Percent \\
\hline Male & 53 & 75.5 & 75.7 \\
\hline Female & 17 & 24.3 & 100.0 \\
\hline \multicolumn{4}{|l|}{ Age } \\
\hline $15-25$ years & 13 & 18.6 & 18.6 \\
\hline $26-40$ years & 25 & 35.7 & 54.3 \\
\hline $41-60$ years & 31 & 44.3 & 98.6 \\
\hline Above 60 years & 1 & 1.4 & 100.0 \\
\hline \multicolumn{4}{|l|}{ Education } \\
\hline Post secondary diploma & 21 & 30.0 & 30.0 \\
\hline Bachelor & 39 & 55.7 & 85.7 \\
\hline Master & 9 & 12.9 & 98.6 \\
\hline $\mathrm{PhD}$ & 1 & 1.4 & 100.0 \\
\hline \multicolumn{4}{|l|}{ Employer } \\
\hline State House ( Office of the presidency) & 11 & 15.7 & 15.7 \\
\hline Office of the parliament & 10 & 14.3 & 30.0 \\
\hline Ministry of Finance and Planning & 16 & 22.9 & 52.9 \\
\hline Central Bank & 15 & 21.4 & 74.3 \\
\hline Mogadishu Sea Port & 13 & 18.6 & 92.9 \\
\hline Immigration and Nationalization Authority & 5 & 7.1 & 100.0 \\
\hline \multicolumn{4}{|l|}{ Title } \\
\hline Financial position & 43 & 61.4 & 61.4 \\
\hline Audit position & 10 & 14.3 & 75.7 \\
\hline Other & 17 & 24.3 & 100.0 \\
\hline \multicolumn{4}{|l|}{ Experience } \\
\hline Less than one year & 13 & 18.6 & 18.6 \\
\hline $1-3$ years & 21 & 30.0 & 48.6 \\
\hline $3-7$ years & 25 & 35.7 & 84.3 \\
\hline More than 7 years & 11 & 15.7 & 100.0 \\
\hline
\end{tabular}

\subsection{Size of the Selected Agencies}

According to go tabulation analysis in the table below, Immigration and Nationalization Authority is a small agency employing 10-49 employees, Office of the Presidency, Office of the Parliament and Central Bank are medium institutions employing 50-249 personnel and Ministry of Finance and Planning and Mogadishu Sea Port are giant institutions employing extra than 250 employees 


\section{Small (10-49 employees)}

Immigration and

Office of the Presidency

Nationalization Authority

\subsection{Financial Accountability Dimensions}

The first objective of the study is to examine internal financial control in the federal institutions. The study found that systems of segregation of duties, documentation, authorization, physical control and record keeping exist in the selected federal agencies. In addition, the federal agencies have internal auditors who verify their accounting records.

\section{No}

\section{Table 4: Descriptive Statistics of Internal Control}

1 The accounting personnel of this

agency are separate from purchasing

and cashier duties.

\section{Mean Std. Deviation}

\section{Interpretation}

$3.84 \quad 1.125 \quad$ Good

$3.91 \quad 974 \quad$ Good

2. All economic events of this agency are

supported by adequate documentation.

3. High-ranking officials of this agency authorize all expenditures

4.04

3.96

4.10 .

5. This agency maintains its accounting records those are reasonable detail and fairly reflect the transactions.

Good

The second objective is to examine budget practices of the selected federal institutions of Somalia. The study found that the selected federal institutions utilize their legally adopted budgets. They raise financial resources and expend in compliance with the budget and other financial laws. They use the budget as control device by preparing budget to actual comparison statements and taking corrective actions if variance exists.

No.

Statements

Table 5: Descriptive Statistics of Budgeting

\section{This agency has a budget that} approved by legislative branch.

3.96

3.76

\section{.875}

1.122

Interpretation

8. This agency raises financial resources and expends in compliance with budget and other financial laws.

9 .This agency compares its actual financial results to a legally adopted budget and takes corrective action if variance exists. 10. This agency prepares budget-to-actual comparison statement.

Overall Score
3.94
764

Good

Good

Good 
No.

\section{Statements}

11. This agency follows accounting and financial reporting procedures approved by the accountant general

12. This agency prepares financial statements about its assets, liabilities, expenditures and revenues.

13. The financial statements of this agency are reliable and timely presented for accountability.

14. This agency publishes its financial statements and it is publicly accessible.

\section{Mean Std. Deviation}

$3.93 \quad 1.026$

3.93
.991

1.040

.608
Interpretation

Good

Good

Good

Overall Score

The fourth objective of the study is to identify the existence of external financial audit and oversight on the selected federal institutions of Somalia. The study found that the financial statements of the surveyed institutions are audited by Auditor General of Somalia, an independent Supreme Audit Institution. The Federal Parliament of Somalia also asks these agencies to justify how they raise and use the public resources to provide public services. In addition, sanctions are imposed on the actors when misuse of public resources is found.

\section{Table 7: Descriptive Statistics of Financial Audit and Oversight}

$\begin{array}{llcc}\text { No. } \quad \text { Statement } & \text { Mean } & \text { Std. Deviation } & \text { Interpretation } \\ \text { 15. The financial statements } & 3.90 & 1.052 & \text { Good }\end{array}$

of this agency are audited by an

Good

independent Supreme Audit Institution.

16. The legislative branch asks this

agency to justify how public

resources is raised and used to

provide services.

17.Sanctions are imposed on the

3.60

.967

Good

actors in the case of misusing public

resources for private gain.

Overall Score

3.77

.739

Good

\section{Discussion}

This study assesses the financial accountability in the federal government of Somalia by analyzing four dimensions of financial accountability. The study found that the financial accountability system in the FGS that protects the country against corruption is improving.

This finding confirms the investigative team's conclusion that there is a functional Public Financial Management (PFM) system in place rooted in law and procedure including a system of internal controls and that, the federal government has taken meaningful action to improve the capacity of PFM institutions of government.

The study differs in its scope and time the 2013 self-assessment report that revealed a weak PFM system. The scope of our study was limited to six federal institutions and studied the first year of the FGS (2012-2013) while confirms some of the findings of the self-assessment report.

The self-assessment report found that an internal audit unit has been set up recently but is not yet fully operational and at present is only attempting vouching of transactions; the Accountant General does not prepare annual financial statements for audit instead simple receipts and payments schedules are prepared but are not made available to the public. In addition, the external auditing function is currently weak while parliament does not receive audit reports and therefore there are no debates on audit findings on budget execution.

Our result was subject to limitations: Firstly, this survey reflected the opinions of the selected federal agencies employees. It did not investigate the reality of their assertions. Secondly, this survey did not study the functions of the auditor general and parliamentary sub-committee for financial oversight on public Institutions. We will

study their authorities and responsibilities when the financial year ends (2014). However, this study concludes that the current FGS has made considerable improvements in establishing financial accountability system that can protect the country against corruption.

\section{Conclusion}

The purpose of this study is to assess the financial accountability in the FGS. The study found that the system of financial accountability in the current FGS is improving. The study recommends to the FGS to upgrade internal controls and financial reporting systems; publish significant budget information in a regular and timely manner to 
the public; promote public participation in the budget process and strength the parliamentary committee for finance and planning and auditor general to carry out their functions effectively. The study also suggests to the civil society organizations and donor agencies to play a more active role in promoting transparency and financial accountability in Somalia.

\section{References}

Accountability Journal, 14(3), 278-310. and Eritrea pursuant to Security Council resolution 2060 (2012): Somalia. Puntland State Bank of Somalia. (2013). Preliminery Response to Allegations of Corruption.

Chene, M. (2012). Overview of Corruption and Anti-corruption in puntland state of Somalia.

Curtin, D., \& Nollkaemper, A. (2005). Conceptualizing Accountability in International and European Law. Eritrea. puntland state of Somalia. (2013). Public Financial Management Self-assessment Report and Proposed

FTI Consulting, Inc; Shulman, Rogers, Gandal, Pordy \& Ecker, P.A. . (2013). The Federal Government of Gendron, Y., Cooper, D. J., \& Townley, B. (2001). In The Name of Accountability. Accounting, Auditing and International Budget Partnership. (2012). Open Budget Survey.

Netherlands Yearbook of International Law, XXXVI, 3-20.

New York: McGraw-Hill Irwin.

Office of the Spokesman of the president of the Federal Republic of Somalia. (2013). International Investigative Operations Evaluation Department, Washington, D.C.

Public Financial Management Strengethining Initiative (2013-2016).

Sahgal, V., \& Chakrapani, D. (2000). Clean Government and Public Financial Accountability. World Bank,

Somalia's response to annex 5.2 of the report of the United Nations Monitoring Group on Somalia and Team Clears Somalia of UN Report Allegations. Mogadishu. Testimoney.

Transparency International. (2013). Corruption Perceptions Index. Transparency International. Retrieved from Transparency.org

United Nations Monitoring Group on Somalia and Eritrea. (2013). Report of the Monitoring Group on Somalia United States Government Accountability Office. (2005). Effective Internal Control is Key to Accountability. Wilson, E. R., Reck, J. L., \& Kattelus, S. C. (2010). Accounting for Governmental \& Nonprofit Entities (15 ed.). 